\title{
The choroid plexus response to a repeated peripheral inflammatory stimulus
}

\author{
Fernanda Marques ${ }^{1}$, João C Sousa1, Giovanni Coppola², \\ Daniel H Geschwind ${ }^{2}$, Nuno Sousa ${ }^{1}$, Joana A Palha ${ }^{1}$ and Margarida Correia- \\ Neves*1
}

\author{
Address: ${ }^{1}$ Life and Health Sciences Research Institute (ICVS), School of Health Sciences, University of Minho, Campus Gualtar, $4710-057$ Braga, \\ Portugal and 2 Program in Neurogenetics, Department of Neurology, David Geffen School of Medicine-UCLA, Los Angeles, USA \\ Email: Fernanda Marques -fmarques@ecsaude.uminho.pt; João C Sousa - jcsousa@ecsaude.uminho.pt; \\ Giovanni Coppola - gcoppola@ucla.edu; Daniel H Geschwind - dhg@ucla.edu; Nuno Sousa - njcsousa@ecsaude.uminho.pt; \\ Joana A Palha - japalha@ecsaude.uminho.pt; Margarida Correia-Neves* - mcorreianeves@ecsaude.uminho.pt \\ * Corresponding author
}

Published: 18 November 2009

BMC Neuroscience 2009, 10:135 doi:10.1 186/1471-2202-10-135

This article is available from: http://www.biomedcentral.com/I47/-2202/10/135

(c) 2009 Marques et al; licensee BioMed Central Ltd.

This is an Open Access article distributed under the terms of the Creative Commons Attribution License (http://creativecommons.org/licenses/by/2.0), which permits unrestricted use, distribution, and reproduction in any medium, provided the original work is properly cited.
Accepted: 18 November 2009
Received: I July 2009

\begin{abstract}
Background: Chronic systemic inflammation triggers alterations in the central nervous system that may relate to the underlying inflammatory component reported in neurodegenerative disorders such as multiple sclerosis and Alzheimer's disease. However, it is far from being understood whether and how peripheral inflammation contributes to induce brain inflammatory response in such illnesses. As part of the barriers that separate the blood from the brain, the choroid plexus conveys inflammatory immune signals into the brain, largely through alterations in the composition of the cerebrospinal fluid.

Results: In the present study we investigated the mouse choroid plexus gene expression profile, using microarray analyses, in response to a repeated inflammatory stimulus induced by the intraperitoneal administration of lipopolysaccharide every two weeks for a period of three months; mice were sacrificed 3 and 15 days after the last lipopolysaccharide injection. The data show that the choroid plexus displays a sustained response to the repeated inflammatory stimuli by altering the expression profile of several genes. From a total of 24,000 probes, 369 are up-regulated and 167 are down-regulated 3 days after the last lipopolysaccharide injection, while at 15 days the number decreases to 98 and 128 , respectively. The pathways displaying the most significant changes include those facilitating entry of cells into the cerebrospinal fluid, and those participating in the innate immune response to infection.
\end{abstract}

Conclusion: These observations contribute to a better understanding of the brain response to peripheral inflammation and pave the way to study their impact on the progression of several disorders of the central nervous system in which inflammation is known to be implicated. 


\section{Background}

Inflammation is implicated in the appearance and in the progression of central nervous system (CNS) diseases such as multiple sclerosis (MS) and Alzheimer's diseases (AD), although the mechanism underlying such involvement is poorly understood [1-4]. It is recognized that the inflammation observed in the CNS of subjects with some of these diseases may originate in the periphery [5-7], particularly when the inflammatory stimulus is persistent. Persistence may be due to chronic inflammation or to repeated exposure to acute inflammatory stimulus for long periods of time. Of relevance, persistent or chronic inflammatory signals result in excessive microglia activation and cause localized or disseminated tissue dysfunction and damage [8], ultimately resulting in accentuation of brain pathology.

The blood-brain barriers, constituted by the endothelial cells of the blood capillaries (blood-brain barrier-BBB) and by the epithelial cells of the choroid plexus (CP) that separate the blood from the cerebrospinal fluid (CSF), are key players in the communication between the periphery and the brain. However, most studies published to date address the $\mathrm{BBB}$ interactions in response to acute peripheral stimulus or in the context of CNS diseases $[9,10]$. Recently, we showed that the blood-CSF barrier is also an important mediator of acute peripheral inflammation into the CNS [11]. Of notice, this response triggers molecular pathways that are commonly viewed as both neuroprotective and deleterious for the brain. Whilst the secretion of proinflammatory cytokines into the CSF, the decreased expression of proteins that form the epithelial cells tight junctions and the increased expression of proteins that may facilitate leukocyte trafficking into the brain might be predicted to display deleterious effects, the response can be also consider protective since it modulates iron metabolism in a way that may prevent microorganism replication in the CSF and, consequently, dissemination within the brain $[12,13]$. While these observations associate the $\mathrm{CP}$ response to acute peripheral inflammation, they raise the possibility that the CP may as well be equipped to mount a sustained response to persistent peripheral inflammatory stimuli.

Importantly, scattered but relevant reports have shown that the CP may contribute to the aetiology of CNS diseases in which persistent, rather than acute inflammation, is more likely to trigger CNS disease. In MS, and in animal models of MS, the CP was proposed as the main route of leukocyte entry into the brain $[14,15]$. In $\mathrm{AD}$, it was proposed that the CP participates in amyloid $\beta$ peptide clearance out of the brain through CSF carrier proteins (e.g. transthyretin and apolipoprotein J) [16] that bind to receptors (e.g. megalin) [17] in the apical membrane of the CP epithelial cells.
These observations prompted us to investigate, using microarray analysis, how the $\mathrm{CP}$ transmits immune signals into the brain in response to peripheral repetitive inflammation. We found that the CP displays a low intensity, but sustained, response to this stimulus and that the leukocyte extravasation signalling pathway as well as pathways that mediate the innate immune response to infection are the most altered both 3 and 15 days after the last LPS injection.

\section{Results \\ Repeated peripheral inflammation induces alterations in the choroid plexus transcriptome}

Mice were administered LPS once every 2 weeks for 3 months and were sacrificed 3 and 15 days after the last LPS injection. The first time-point for sacrifice was chosen taking into account previous reports [11] showing that 3 days after a single LPS injection few genes display an altered expression. Comparing the gene expression profile 3 days after the last LPS injection in the present protocol with that occurring 3 days after a single LPS administration, allowed us to identify the genes whose altered expression is the result of the repeated rather than single exposure to the inflammatory stimuli. Since in the present experimental protocol LPS was administered every 2 weeks for 3 months, the analysis 15 days after the last injection allowed us to evaluate if any changes occurring in the gene expression profile were sustained during repeated exposure to inflammatory stimuli.

During the duration of the experiment, the LPS dose used did not induce any statistical significant changes in the body weight, and the survival rate observed was of $100 \%$. No cage behaviour alterations were observed throughout the experimental period.

Figure 1 shows that 3 days after the last LPS injection 536 probes have an altered expression when compared to the saline injected animals. Since at the same time-point after a single LPS injection [11], only 46 genes were found to have an altered expression, this response depends on the chronic nature of the stimuli. Moreover, a response of the $\mathrm{CP}$ to the continuous peripheral stimuli is still present 15 days after the last injection, with the expression of 226 genes altered. This suggests that, contrary to what is observed upon a single acute stimulus, repetitive LPS injections do not allow the CP gene expression profile to restore to its basal levels in a short period of time.

Despite the number of genes whose expression is found altered, not many display a fold change higher than $50 \%$ (Figure 2). In fact, as can be observed in Figure 2a, 3 days after the last LPS injection, only 25 genes out of the 369 genes whose expression is up-regulated display a fold change $\geq 2,0$. In addition, from the 167 genes whose 


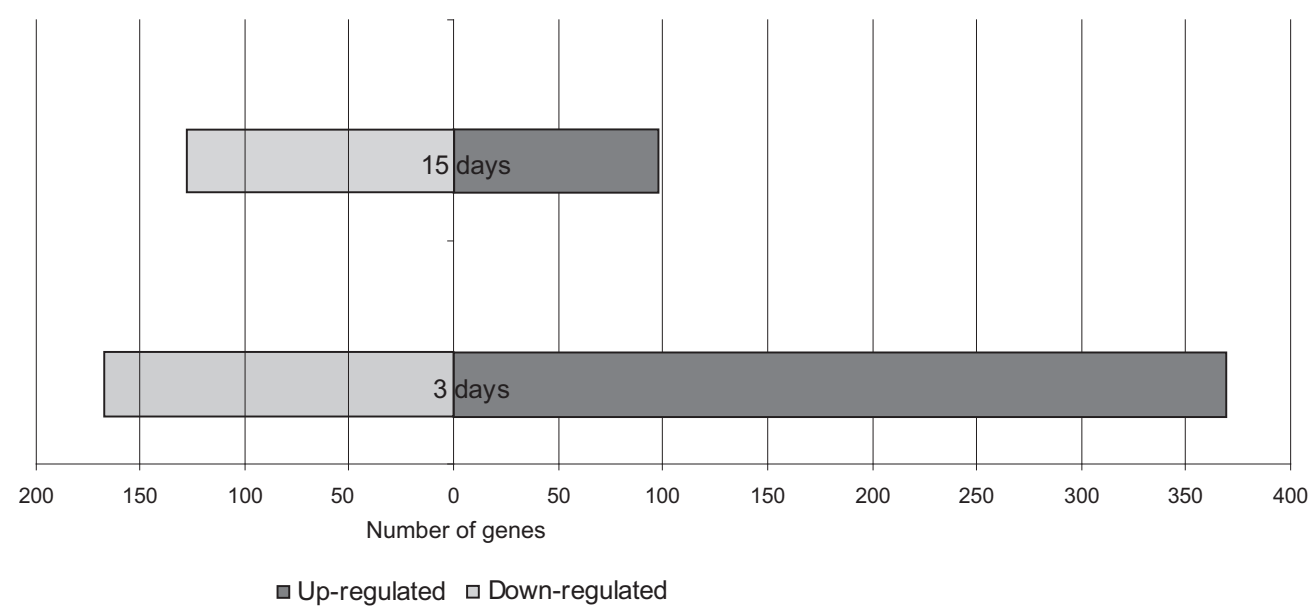

Figure I

Chronic inflammation alters the choroid plexus gene expression profile. Number of genes up-regulated (black) and down-regulated (gray) in the choroid plexus 3 and I 5 days after the last LPS injection. All genes with a variation in expression of at least I0\% (FDR 5\%) were considered.

expression is down-modulated, none shows a strong down-modulation and only 5 display a decrease as low as 1,7 fold (Figure 2a). The fold changes are even smaller (but still statistically significant) at 15 days after the last LPS injection (Figure 2b); only 2 genes present a fold increase $\geq 2,0$.

Table 1 lists, taking into consideration the fold change, the 10 genes whose expression is most altered at 3 and 15 days after the last LPS injection.

a)

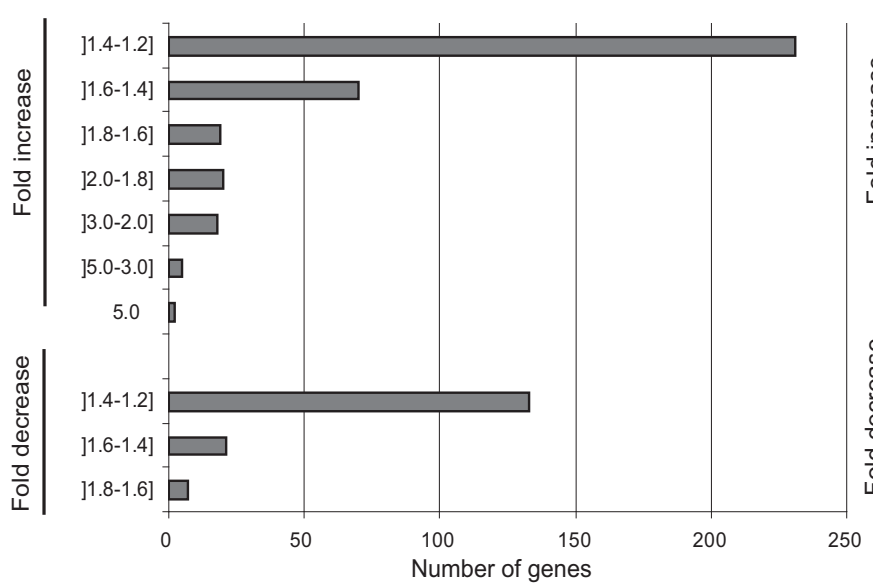

To identify the genes whose altered expression was sustained we looked for those that had at least a $40 \%$ change, both at 3 and at 15 days after the last LPS stimulus. Only 7 up-regulated genes fulfil such criteria (Table 2).

\section{Identification of altered gene pathways}

We next analysed, using the Ingenuity software, the pathways to which the genes with altered expression belong. From Table 3, it is clear that 15 days after the last LPS injection only a few genes within each biological pathway remained with altered expression. Interestingly, the signalling pathways in which a considerable number of b)

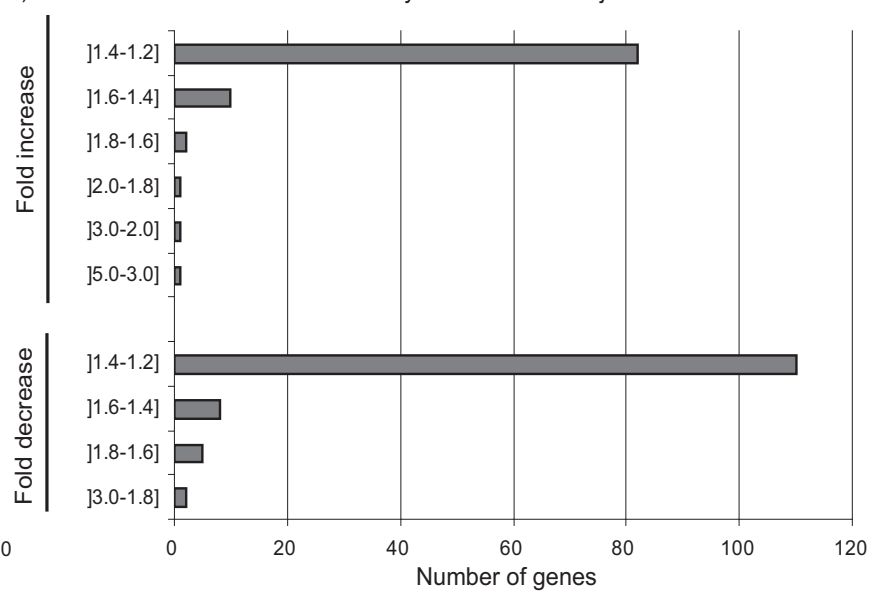

Figure 2

Fold changes in gene expression. The fold change induced in most genes by the chronic stimulus is below $50 \%$, both at 3 days (a) and at 15 days (b) after the last LPS injection. 
Table I: List of genes whose expression is most altered at 3 and I 5 days after last LPS injection.

\begin{tabular}{|c|c|c|c|c|c|c|c|}
\hline \multicolumn{4}{|c|}{3 days after last LPS injection } & \multicolumn{4}{|c|}{ I 5 days after last LPS injection } \\
\hline $\begin{array}{l}\text { Up-regulated } \\
\text { Transcript }\end{array}$ & Symbol & Definition & Fold change & $\begin{array}{l}\text { Up-regulated } \\
\text { Transcript }\end{array}$ & Symbol & Definition & Fold change \\
\hline NM_0II3I5 & Saa3 & Serum amyloid A 3 & 12,1 & NM_016974.I & Dbp & $\begin{array}{l}\mathrm{D} \text { site albumin promoter } \\
\text { binding protein }\end{array}$ & 3,3 \\
\hline NM_008I6I.I & Gpx3 & Glutathione peroxidase 3 & 6,7 & NM_I45434.I & Nrldl & $\begin{array}{l}\text { Nuclear receptor } \\
\text { subfamily I group D } \\
\text { member I }\end{array}$ & 2,5 \\
\hline NM_017372.2 & Lyzs & Lysozyme & 4,2 & NM_008I76.I & Cxcll & $\begin{array}{l}\text { Chemokine (C-X-C } \\
\text { motif) ligand I }\end{array}$ & 1,9 \\
\hline NM_009252.I & Serpina3n & $\begin{array}{l}\text { Serine (or cysteine) } \\
\text { proteinase inhibitor clade } \\
\text { A member } 3 \mathrm{~N}\end{array}$ & 3,8 & NM_0I7372.2 & Lyzs & Lysozyme & $\mathrm{I}, 7$ \\
\hline NM_008I34.I & Glycam I & $\begin{array}{l}\text { Glycosylation dependent } \\
\text { cell adhesion molecule I }\end{array}$ & 3,7 & NM_0II328.I & Sct & Secretin & 1,6 \\
\hline NM_030707 & Msr2 & $\begin{array}{l}\text { Macrophage scavenger } \\
\text { receptor } 2\end{array}$ & 3,2 & NM_008I6I.I & Gpx3 & Glutathione peroxidase 3 & 1,5 \\
\hline NM_013653.I & Ccl5 & $\begin{array}{l}\text { Chemokine (C-C motif) } \\
\text { ligand } 5\end{array}$ & 3,1 & NM_I75030.I & TctexId4 & $\begin{array}{l}\text { Tctexl domain } \\
\text { containing } 4\end{array}$ & 1,5 \\
\hline NM_0I0I85.2 & Fcerlg & $\begin{array}{l}\text { Fc receptor lgE high affinity } \\
\text { I gamma polypeptide }\end{array}$ & 2,9 & NM_010493.2 & Icam I & $\begin{array}{l}\text { Intercellular adhesion } \\
\text { molecule }\end{array}$ & 1,5 \\
\hline NM_007574.I & $\mathrm{Clqg}$ & $\begin{array}{l}\text { Complement component I } \\
\text { q subcomponent gamma } \\
\text { polypeptide }\end{array}$ & 2,8 & NM_009778.I & $\mathrm{C} 3$ & $\begin{array}{l}\text { Complement component } \\
3\end{array}$ & $\mathrm{I}, 4$ \\
\hline NM_00849I.I & Len2 & Lipocalin 2 & 2,7 & NM_030707 & Msr2 & $\begin{array}{l}\text { Macrophage scavenger } \\
\text { receptor } 2\end{array}$ & $\mathrm{I}, 4$ \\
\hline \multicolumn{4}{|c|}{ Down-regulated } & \multicolumn{4}{|c|}{ Down-regulated } \\
\hline Transcript & Symbol & Definition & Fold change & Transcript & Symbol & Definition & Fold change \\
\hline XM_355574.I & Gnail & $\begin{array}{l}\text { Guanine nucleotide binding } \\
\text { protein alpha inhibiting I }\end{array}$ & $-1,7$ & NM_007489.I & Arntl & $\begin{array}{l}\text { Aryl hydrocarbon } \\
\text { receptor nuclear } \\
\text { translocator-like }\end{array}$ & $-2,8$ \\
\hline NM_I 77644.2 & Rasal2 & $\begin{array}{l}\text { RAS protein activator like } \\
2\end{array}$ & $-1,7$ & NM_I75475.2 & Сyp26bl & $\begin{array}{l}\text { Cytochrome P450 family } \\
26 \text { subfamily b } \\
\text { polypeptide I }\end{array}$ & $-2,3$ \\
\hline NM_018824.2 & Slc23a2 & $\begin{array}{l}\text { Solute carrier family } 23 \\
\text { (nucleobase transporters) } \\
\text { member } 2\end{array}$ & $-1,7$ & NM_I33903.2 & Spon2 & $\begin{array}{l}\text { Spondin } 2 \text { extracellular } \\
\text { matrix protein }\end{array}$ & $-1,7$ \\
\hline NM_0II638.3 & Tfre & Transferrin receptor & $-1,7$ & NM_029720.I & Creld2 & $\begin{array}{l}\text { Cysteine-rich with EGF- } \\
\text { like domains } 2\end{array}$ & $-1,6$ \\
\hline NM_I 78404.2 & Zc3hdc6 & $\begin{array}{l}\text { Zinc finger } \mathrm{CCCH} \text { type } \\
\text { containing } 6\end{array}$ & $-1,7$ & NM_I75930.2 & Rapgef5 & $\begin{array}{l}\text { Rap guanine nucleotide } \\
\text { exchange factor (GEF) } 5\end{array}$ & $-1,6$ \\
\hline NM_013519.1 & Foxc2 & Forkhead box $\mathrm{C} 2$ & $-1,6$ & NM_198885.2 & Scx & Scleraxis & $-1,6$ \\
\hline NM_I48930.2 & Rbm5 & $\begin{array}{l}\text { RNA binding motif protein } \\
5\end{array}$ & $-1,6$ & NM_I75930.2 & Rapgef5 & $\begin{array}{l}\text { Rap guanine nucleotide } \\
\text { exchange factor (GEF) } 5\end{array}$ & $-1,6$ \\
\hline NM_I72310.I & Tarsl2 & $\begin{array}{l}\text { Threonyl-tRNA } \\
\text { synthetase-like } 2\end{array}$ & $-1,5$ & NM_20726I.I & Kcnkl8 & $\begin{array}{l}\text { Potassium channel, } \\
\text { subfamily K, member } 18\end{array}$ & $-1,5$ \\
\hline NM_02802I.I & MyhI4 & $\begin{array}{l}\text { Myosin, heavy polypeptide } \\
\text { 14 }\end{array}$ & $-1,5$ & NM_013559.1 & Hspl05 & Heat shock protein 105 & $-1,4$ \\
\hline NM_009222.2 & Snap23 & $\begin{array}{l}\text { Synaptosomal-associated } \\
\text { protein } 23\end{array}$ & $-1,5$ & NM_030I43.2 & Ddit4l & $\begin{array}{l}\text { DNA-damage-inducible } \\
\text { transcript 4-like }\end{array}$ & $-1,4$ \\
\hline
\end{tabular}

genes still have altered expression 15 days after the last injection of LPS are those related with leukocyte migration and with the complement cascade signalling.

In a previous report we characterized the kinetic gene expression profile [from $1 \mathrm{~h}$ up to 3 days] in response to a single LPS peripheral injection [11]. When the transcriptome of the CP at 3 days after this acute inflammatory stimulus is compared to that observed 3 days after the last injection of the repeated protocol reported here, it should be noted that: only 4 genes (rather than 12) of the acute phase response signalling pathway, 2 genes (rather than 7) encoding for chemokines, 2 genes (rather than 5) of the complement system and 3 (rather than 4) from the antigen presentation pathway are common in both responses. All other pathways, such as that involved in axonal guid- 
Table 2: Genes whose expression is at least $40 \%$ up-regulated both at 3 and 15 days after the last LPS injection.

Genes altered 3 and 15 days after last LPS injection

\begin{tabular}{|c|c|c|c|c|}
\hline \multirow[b]{2}{*}{ Transcript } & \multirow[b]{2}{*}{ Symbol } & \multirow[b]{2}{*}{ Definition } & \multicolumn{2}{|c|}{ Fold change } \\
\hline & & & 3 days & I5 days \\
\hline NM_008I6I.I & Gpx3 & Glutathione peroxidase 3 & 6,7 & 1,5 \\
\hline NM_017372.2 & Lyzs & Lysozyme & 4,2 & $\mathrm{I}, 7$ \\
\hline NM_030707 & Msr2 & Macrophage scavenger receptor 2 & 3,2 & $\mathrm{I}, 4$ \\
\hline NM_009778.I & $\mathrm{C} 3$ & Complement component 3 & 2,6 & $\mathrm{I}, 4$ \\
\hline NM_008I76.I & Cxcll & Chemokine (C-X-C motif) ligand I & 2,0 & 1,9 \\
\hline NM_0II328.I & Sct & Secretin & 1,6 & $\mathrm{I}, 6$ \\
\hline NM_0I0493.2 & Icam I & Intercellular adhesion molecule & 1,5 & 1,5 \\
\hline
\end{tabular}

ance signalling, are only implicated when repeated stimuli are imposed, suggesting that most of these alterations are certainly associated with the chronicity of the model reported here.

\section{Confirmation of array results by qRT-PCR on a set of relevant genes}

Within each pathway, and using RNA extracted from CP pools of an independent experiment, a number of genes found up-regulated (Lcn2, Serpin3n, Saa3, Cxcl1, Gpx3 and Glycam1) were chosen for qPCR analysis; this analysis confirmed the array data. Figure 3 exemplifies the expression levels of some of these genes. Relatively to the downregulated genes although all the genes tested showed a decreased expression they did not reach statistical significance (data not shown); this could be due to the fact that all the down-regulated genes showed only a slightly decrease in the array (Figure 2).

\section{Discussion and conclusion}

This study shows that sustained peripheral inflammation induced by repeated administration of LPS, every 2 weeks for 3 months, causes an altered CP transcriptome, 3 and 15 days after the last LPS injection. We have previously shown that an acute LPS injection triggers a rapid and transient alteration in the $\mathrm{CP}$ gene expression profile, that returns almost to basal levels after 3 days. In this study, we show that facing repeated LPS stimuli the number of genes whose expression is altered in the $\mathrm{CP}$, compared with the number of genes altered 3 days after an acute LPS injection, is much higher. Another important difference is that when compared the present study with the overall CP response to acute LPS it is clear that the magnitude of the fold changes is now much lower. Therefore, we can conclude that the chronicity of the inflammatory stimuli alters the dynamics of the CP response. Indeed, it seems that the repeated injection of LPS induces, in the CP, a sustained transcription of specific genes encoding for molecules already found transiently altered upon a single LPS injection. These include molecules known to participate in the host response against microorganisms, elements of the complement and chemokines.

When the overall CP response is evaluated in terms of the major biological pathways, 3 days after the last LPS administration, the $\mathrm{CP}$ response is mainly characterized by the increased expression of genes encoding for chemokines, molecules of the complement, and molecules involved in leukocyte extravasation signalling and in the activation of NK, T and B cells. As expected, genes belonging to signalling transduction pathways are similarly altered and are known to mediate the regulation of genes encoding for molecules such as cytokines and molecules of the complement. Of notice, it is well established that a chronic inflammation can result in the inappropriate recruitment of leukocytes and cause localized or disseminated tissue dysfunction and damage. The "leukocyte extravasation signaling" pathway seems, in fact, the most altered both at 3 and 15 days after the last LPS treatment. This includes the increased expression of genes encoding for cell adhesion molecules such as ICAM-1, glycosylation dependent cell adhesion molecule 1 (Glycam1), mucosal vascular addressin cell adhesion molecule 1 (Madcam1), junction adhesion molecule 2 (Jam2) and selectin P ligand (Selpl); chemokines that are required for trafficking of immune cells from the blood into tissues such as Xcl1, Ccl7, Cxcl1, Ccl2 and interleukins such as interleukine-16 (IL-16). Of notice, we did not find IL-16 expression influenced by acute inflammation [11]. IL-16 is a pleiotropic cytokine that is a natural ligand of CD4 $[18,19]$ and has been identified at sites of allergic inflammation in both the murine and the human airway epithelium $[20,21]$. This cytokine is known as a chemoattractant for CD4+ $\mathrm{T}$ cells, monocytes, eosinophils and dendritic cells, with preferential chemoattractant activity for the CD4+ Th1 subset [22-24]. Despite the increased expression of genes encoding for molecules that participate in leukocyte recruitment, no changes were observed in the expression levels of genes that encode tight junction proteins, neither an increase in the number of cells was observed in the CSF 
Table 3: Clustering of the genes whose expression is altered in the choroid plexus upon repeated peripheral LPS injection.

\begin{tabular}{|c|c|c|c|}
\hline \multicolumn{4}{|c|}{ Atered genes } \\
\hline & & 3 days & I 5 days \\
\hline \multirow[t]{18}{*}{ Signaling pathways } & Toll like receptor signaling & TIr7; Mapk8; CdI4; Relb $\uparrow$ & - \\
\hline & $\mathrm{T}$ cell receptor signaling & Mapk8; Nfat5;Btk; Vavl; Relb $\uparrow ;$ Rras2; Nfatcl $\downarrow$ & Itk $\uparrow$ \\
\hline & B cell receptor signaling & $\begin{array}{l}\text { Fcgr2a; Bcl2a I; Mapk8; Nfat5; Map2k7; Rac2; } \\
\text { Fcgr2b; Inpp5d; Btk; VavI; Relb } \uparrow ; \text { Rras2; Nfatcl; } \\
\text { Bcl2II } \downarrow\end{array}$ & - \\
\hline & SAPK JNK signaling & $\begin{array}{l}\text { Gpr65; Gpr24; Mapk8; Map2k7; Rac2; Sh2d2a } \uparrow \text {; } \\
\text { Rras2; Fadd; Nfatcl; Egfr } \downarrow\end{array}$ & GngI I;Gpr34 个; Dusp8 $\downarrow$ \\
\hline & Natural killer signaling & $\begin{array}{l}\text { Fcer Ig; Tyrobp; Siglec7; Rac2; KIrd I; Inpp5d; Vavl; } \\
\text { Hcst } \uparrow \text {; Rras2 } \downarrow\end{array}$ & KIrdI; Siglec7 $\uparrow$ \\
\hline & NF-kB signaling & 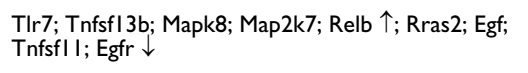 & Tnfsfl3b $\uparrow$ \\
\hline & JAK/STAT signaling & Stat3 $\uparrow ;$ Rras $2 \downarrow$ & - \\
\hline & cAMP mediated signaling & 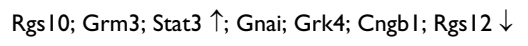 & Adcy9; Crem $\downarrow$ \\
\hline & Interferon signaling & 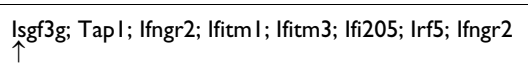 & Ifitml $\uparrow$ \\
\hline & GM-CSF signaling & Bcl2al; Stat3 个; Rras2; Bcl2II $\downarrow$ & - \\
\hline & Integrin signaling & Mapk8; Actin4; Rac2 个; Rras2; Egfr $\downarrow$ & Itgae; Itgb7 $\uparrow$ \\
\hline & IL-I0 signaling & IIIOra; Tcgr2a; Mapk8; CdI4; Fcgr2b; Stat3; Relb $\uparrow$ & - \\
\hline & IL-6 signaling & Mapk8; Map2k7; CdI4; Stat3; Relb 个; Rras2 $\downarrow$ & - \\
\hline & IL-4 signaling & Nfat5; II2rg; Inpp5d 个; Rras2; Nfatcl $\downarrow$ & - \\
\hline & IL-2 signaling & Mapk8; II2rg $\uparrow ;$ Rras2 $\downarrow$ & - \\
\hline & Complement/coagulation cascade signaling & C3; Clqa; Clqb; Clqg; Vwf; Serpingl; C2 $\uparrow$ & Serpind I; Cl qg; Cl qa; C3 $\downarrow$ \\
\hline & Apoptosis signaling & $\begin{array}{l}\text { Casp I; Bcl2al; Mapk8; Map2k7; Relb 个; Rras2; } \\
\text { Bcl2II; Ecfr; Bcl2 }\end{array}$ & Cardl4 4 \\
\hline & Antigen presentation pathway & B2m; H2-T23; Tapl; Psmb9 $\uparrow$ & - \\
\hline Acute phase response & Acute phase proteins & $\begin{array}{l}\text { Serping I; Map2k7; C3; Mapk8;Saa3;Vwf; Stat3; Slp; } \\
\text { C2; serpina3n } \uparrow ; \text { Fn I; Rras2 } \downarrow\end{array}$ & $\mathrm{C} 3 \uparrow$ \\
\hline \multirow[t]{5}{*}{ Leukocyte migration } & Leukocyte extravasation signaling & $\begin{array}{l}\text { Ncf2; Selpl; Mapk8; Cyba; Jam2; Actn4; Rac2; } \\
\text { Mmp23; Icam I; Glycam I; Madcam I; TimpI; Btk; } \\
\text { VavI } \uparrow \text {; Gnai } \downarrow\end{array}$ & Icam I; Itk; Cyba $\uparrow$ \\
\hline & Extracellular matrix & $\begin{array}{l}\text { Timpl; Dcn; Lamb2; Fbln I; Mmp23; Tecta; EmidI 个; } \\
\text { FnI } \downarrow\end{array}$ & Tnc; Spon2 $\downarrow$ \\
\hline & Cytokine signaling & $\begin{array}{l}\text { III6; Ccl5; Cxcll; Ccl7; Ccll3; Xcll; Cxcll6; Ccl2 } \uparrow \text {; } \\
\text { Gnail; Rras2 }\end{array}$ & Cxcll; Ccl7; Xcll; Ccl2 \\
\hline & Actin cytoskeleton signaling & $\begin{array}{l}\text { Nckap Il; Gpr65; Gpr34; Actn4; Kngl; Rac2; CdI4; } \\
\text { VavI } \uparrow ; \text { Rras2; Fgf7; Egf; Myh I4; Fn I; Egfr } \downarrow\end{array}$ & Gpr34 \\
\hline & Axonal guidance signaling & $\begin{array}{l}\text { Igfl; Nfat5; Rac2; Fes } \uparrow \text {; Gnail; Slit2; Rras2; Rgma; } \\
\text { Nfatc I; Egf; Egfr } \downarrow\end{array}$ & Rgmb $\uparrow$ \\
\hline
\end{tabular}



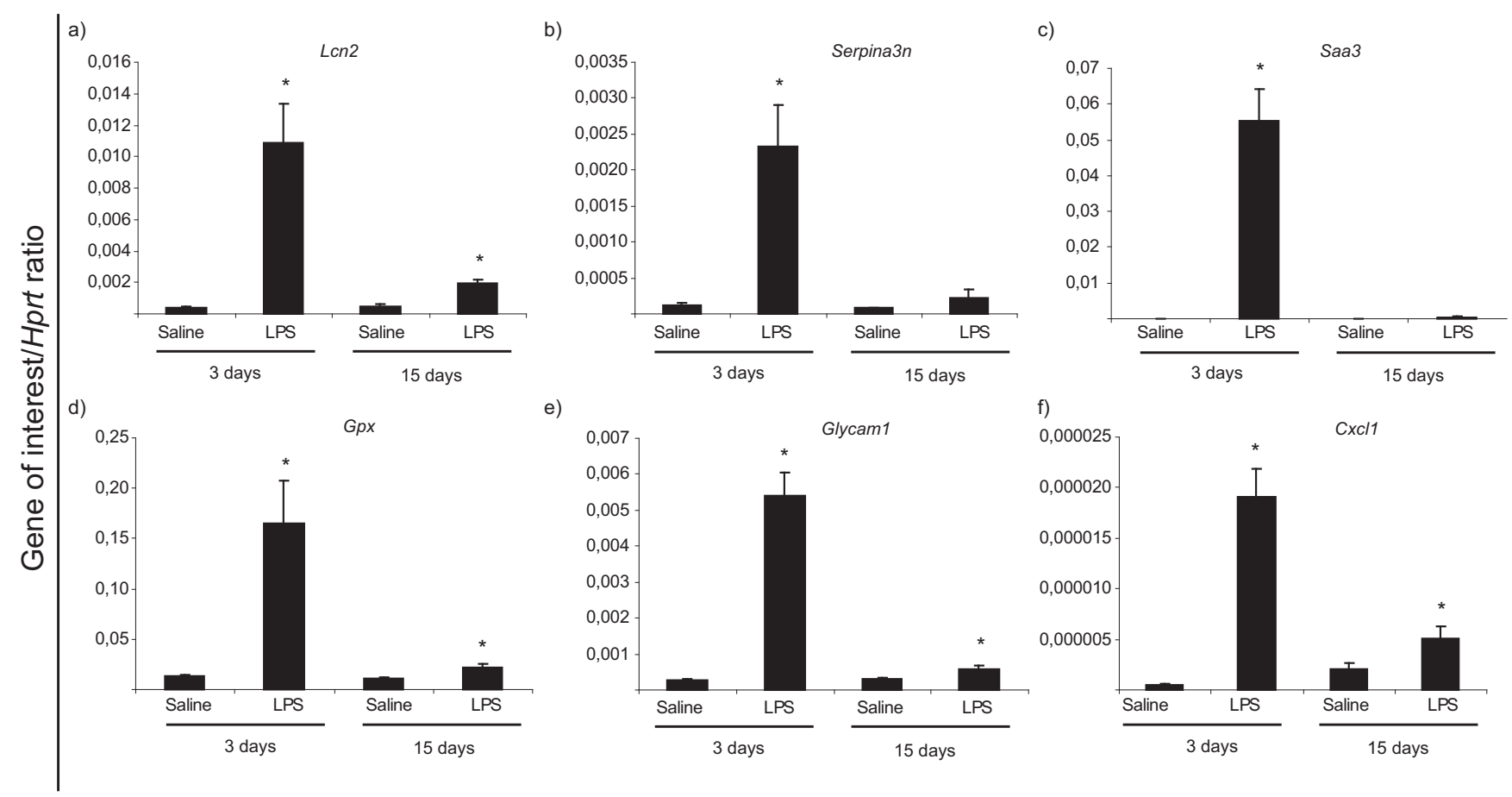

Figure 3

qRT-PCR analysis of the expression of selected genes. Confirming the array results, the expression of $L c n 2$, Serpina3n, Saa3, Cxcll, Gpx3, and Glycam I (a-f) was found up-regulated by qRT-PCR.

or gross morphological changes in the $\mathrm{CP}$ (data not shown). It is therefore important to further understand whether the repeated exposure to peripheral inflammation ultimately results in the entry of immune cells into the brain, or whether additional conditions are necessary for such to occur.

Another interesting finding is the effect of repeated exposure to LPS in the expression of genes that encode for proteins involved in axonal guidance. This suggests that the chronicity of the stimulus can induce alterations in the normal neuronal morphology and neuronal plasticity. One of such molecules whose gene expression is decreased is the slit homolog 2 (Slit2). Interestingly SLIT, a secreted protein known for its role of repulsion in axon guidance and neuronal migration $[25,26]$, can also inhibit leukocyte chemotaxis induced by chemotactic factors [26]. In addition to Slit2, the expression of the gene encoding for the RGM domain family member A (Rgma) is decreased in the $\mathrm{CP}$ after sustained inflammation. RGMa is suggested to inhibit axon growth and synapse formation [27]. In normal brains, RGMa expression is detected on the perikarya of some neurons, $\mathrm{CP}$, smooth muscle, endothelial cells, oligodendrocytes, and myelinated white matter fibers [28]. Interestingly, and probably also with impact on the brain parenchyma, is the altered expression of the gene encoding for secretin which is increased at both time points analysed, and one of the most altered 15 days after the last LPS injection. The secretin gene is known to be expressed in several developing brain regions namely by the CP [29]. The up regulation of its expression may be protective for the brain parenchyma in response to LPS since secretin deficient mice display impaired synaptic plasticity in the CA1 area of the hippocampus [30] and given the neuroprotective role secretin exerts on neuronal progenitor cells against ethanol-mediated neurotoxicity [31]. While some proteins secreted into the CSF may exert a function in the brain parenchyma, others may influence the CP in itself. Among these is glutathione peroxidase 3 . By participating in the detoxification of reactive oxygen spices, which are formed during an inflammatory response, the increased expression of this antioxidant defence enzyme [32] can be protective to the CP epithelial cells.

Further comparison between the gene expression profiles after exposure to a single or to repeated LPS injections, shows that in chronicity the fold change is considerably smaller. However, it should be noted that the expression of some CP genes seems solely altered after the repeated stimulation. Among these are genes encoding for proteins of the S100 family. The S100 family of calcium-binding proteins comprises a new group of pro-inflammatory molecules that has been discussed in the context of MS 
[33] and of $\mathrm{AD}$ [34]. Here we show increased levels of S100a8 and S100a9. Another molecule exclusively induced during the chronic treatment is the macrophage scavenger receptor 2 (Msr2). Scavenger receptors (SRs), initially described on macrophages as high-affinity receptors for acetylated low-density lipoproteins, comprise several receptor classes $[35,36]$ and are expressed in various cell types. SRs have a role in the binding and internalization of many unrelated ligands, such as fibrillar $\beta$-amyloid, lipids, glycated collagen and apoptotic cells and, therefore, are important for tissue homeostasis. The upregulated expression of this gene could indicate a protective role of the CP in the progression of diseases such as $\mathrm{AD}$. As referred above, clearance of amyloid $\beta$ peptide out of the brain is reported to occur through the megalin and low-density lipoprotein receptor-related protein receptors that are SRs [37].

The CP is composed of a vascularized stroma surrounded by a tight layer of epithelial cells that are responsible for producing most of the CSF. Therefore any alteration in the $\mathrm{CP}$ gene expression profile may influence the CSF composition, which may then be transmitted to the brain parenchyma. While many of the genes whose expression we found altered in the present study are expressed in the CP epithelial cells $[11,12]$, we cannot exclude the contribution of other cells of the CP stroma, such as endothelial cells and macrophages in the observed response.

In summary, we describe here that the $\mathrm{CP}$ displays a sustained response to a repeated inflammatory stimulus induced in the periphery. Importantly, this response seems to share some mechanisms previously described for the $\mathrm{BBB}$, which include the activation of adhesion and chemoattraction signals in endothelial cells in CNS diseases such as MS [9,38]. Therefore, both the blood-CSF barrier and the BBB seem equipped to convey signals to the brain parenchyma in response to both acute and chronic inflammation. Future studies should further investigate the role of the $\mathrm{CP}$ response in the context of CNS disorders.

\section{Methods}

\section{Animals and LPS injection}

All experiments were conducted using 8-9 week-old C57BL/6 male mice (Charles River, Barcelona, Spain), in accordance with the European Community Council Directive 86/09/EEC guidelines for the care and handling of laboratory animals. Animals were maintained in $12 \mathrm{~h}$ light/dark cycles at $22-24^{\circ} \mathrm{C}$ and $55 \%$ humidity and fed with regular rodent's chow and tap water ad libitum. Animals were handled for 1 week prior to the beginning of the experiment, in order to reduce the stress induced by the injection. Animals were given LPS (Escherichia coli, serotype O26:B6; Sigma, St. Louis, USA) ( $5 \mu \mathrm{g} / \mathrm{g}$ body weight) intraperitoneally (i.p.); control animals were injected with vehicle $(0.9 \% \mathrm{NaCl})$ alone. Mice received i.p. LPS or vehicle once every 2 weeks for 3 months. Animals were sacrificed 3 or 15 days after the last injection, under anesthesia with ketamine hydrochloride $(150 \mathrm{mg} /$ $\mathrm{Kg})$ plus medetomidine $(0.3 \mathrm{mg} / \mathrm{Kg})$, and transcardially perfused with cold saline. CP isolation was made under conventional light microscopy (SZX7, Olympus, Hamburg, Germany) and tissue was rapidly removed, frozen in dry ice and stored at $-80^{\circ} \mathrm{C}$. For the microarray experiment three polls of CP (from 3 animals each) were prepared for each experimental group and for each time point. For the qRT-PCR study five pools of CP (from 3 animals each) were used for each experimental group and for each time point.

\section{Microarray experimental design and data analysis}

Total RNA was isolated using Trizol reagent (Invitrogen, Calrsbad, CA, USA). Total RNA quality was assessed using the Agilent Bioanalyzer (Santa Clara, CA, USA). After quality assessment, $100 \mathrm{ng}$ of total RNA from 3 control pools and 3 LPS pools, for each time point, were amplified and labelled with Illumina TotalPrep RNA Amplification Kit according to manufacturer instructions. Each pool was composed of $\mathrm{CP}$ collected from 3 animals. The labelled cRNA was then hybridized using Illumina recommended protocol in a total of two Illumina Wholegenome Mouseref- 8 expression Beadchips (San Diego, CA, USA). This mouse beadchip contains eight arrays, each comprising a total of 24,000 well-annotated RefSeq transcripts.

After scanning, raw data from BeadStudio software (San Diego, CA, USA) was read into R/Bioconductor. Quality control using inter-array Pearson correlation and clustering based on variance allowed us to ensure that there was reproducibility between the replicates (data not shown). Data was normalized using quantile normalization. A linear model was applied to the normalized data using Limma package in R/Bioconductor [39]. The CP transcriptome of the LPS injected animals was analysed and compared with that of control animals. A contrast analysis was applied and differentially expressed genes were selected using a Bayesian approach with a false discovery rate (FDR) of 5\%. The differentially expressed genes were categorized using Gene Ontology from Biomart http:// www.biomart.org/ or Ingenuity tools (Redwood City, CA, USA). Enrichment analysis was performed using the DAVID http://david.niaid.nih.gov/david/ease.htm and the Ingenuity software's.

\section{Gene expression measurements by $q R T-P C R$}

$500 \mathrm{ng}$ of total RNA, isolated as described above, were amplified using a SuperScript RNA Amplification System (Invitrogen) according to the manufacturer's instructions. 
After amplification, RNA was reverse transcribed into first strand cDNA using random hexamers of the superscript first-strand synthesis system for RT-PCR (Invitrogen).

qRT-PCR analysis was used to measure the expression levels of selected mRNA transcripts. Primers were designed using the Primer3 software [40] on the basis of the respective GenBank sequences. The expression level of the reference gene hypoxanthine guanine phosphoribosyl transferase (Hprt) (accession number from GenBank: NM 013556) was used as internal standard for normalization. All the other accession numbers and primers sequences are available upon request. Reactions using equal amounts of total RNA from each sample were carried out on a CFX $96^{\mathrm{Tm}}$ real-time system instrument (BioRad Laboratories, Hercules, CA, USA) with the QuantiTect SYBR Green RT-PCR reagent kit (Qiagen, Hamburg, Germany) according to the manufacturer's instructions. Product fluorescence was detected at the end of the elongation cycle. All melting curves exhibited a single sharp peak at the expected temperature.

\section{Statistical analysis}

Values are reported as mean \pm SEM. Statistical significance was determined using the non-parametric Mann-Whitney test, with differences considered significant at $\mathrm{p}<0.05$.

\section{Authors' contributions}

JAP, MCN, JCS, NS: conception and design, analysis and data interpretation. FM, JCS: conception and design, acquisition of data and analysis and interpretation of data. GC, DHG: microarray analysis and data interpretation. All authors read and approved the final manuscript.

\section{Acknowledgements}

This work was supported by a grant from the DANA foundation; Marques $F$ is recipient of a fellowship from Fundação para a Ciência e Tecnologia FCT/FEDER.

\section{References}

I. Cunningham C, Wilcockson DC, Campion S, Lunnon K, Perry VH: Central and systemic endotoxin challenges exacerbate the local inflammatory response and increase neuronal death during chronic neurodegeneration. I Neurosci 2005, 25(40): $9275-9284$.

2. Chen H, O'Reilly EJ, Schwarzschild MA, Ascherio A: Peripheral inflammatory biomarkers and risk of Parkinson's disease. $\mathrm{Am}$ J Epidemiol 2008, I67(I):90-95.

3. Tan ZS, Beiser AS, Vasan RS, Roubenoff R, Dinarello CA, Harris TB, Benjamin EJ, Au R, Kiel DP, Wolf PA, et al.: Inflammatory markers and the risk of Alzheimer disease: the Framingham Study. Neurology 2007, 68(22): 1902-1908.

4. Qin L, Wu X, Block ML, Liu Y, Breese GR, Hong JS, Knapp DJ, Crews FT: Systemic LPS causes chronic neuroinflammation and progressive neurodegeneration. Glia 2007, 55(5):453-462.

5. Bar-Or A: The immunology of multiple sclerosis. Semin Neurol 2008, 28(I):29-45.

6. Cunningham C, Campion S, Lunnon K, Murray CL, Woods JF, Deacon RM, Rawlins JN, Perry VH: Systemic inflammation induces acute behavioral and cognitive changes and accelerates neurodegenerative disease. Biol Psychiatry 2009, 65(4):304-3 I2.
7. Teeling JL, Felton LM, Deacon RM, Cunningham C, Rawlins JN, Perry $\mathrm{VH}$ : Sub-pyrogenic systemic inflammation impacts on brain and behavior, independent of cytokines. Brain Behav Immun 2007, 2 I (6):836-850.

8. Dilger RN, Johnson RW: Aging, microglial cell priming, and the discordant central inflammatory response to signals from the peripheral immune system. J Leukoc Biol 2008, 84(4):932-939.

9. Engelhardt B, Ransohoff RM: The ins and outs of T-lymphocyte trafficking to the CNS: anatomical sites and molecular mechanisms. Trends Immunol 2005, 26(9):485-495.

10. Engelhardt B: Regulation of immune cell entry into the central nervous system. Results Probl Cell Differ 2006, 43:259-280.

II. Marques F, Sousa JC, Coppola G, Falcao AM, Rodrigues AJ, Geschwind DH, Sousa N, Correia-Neves M, Palha JA: Kinetic profile of the transcriptome changes induced in the choroid plexus by peripheral inflammation. J Cereb Blood Flow Metab 2009, 29(5):921-932.

12. Marques F, Rodrigues AJ, Sousa JC, Coppola G, Geschwind DH, Sousa $\mathrm{N}$, Correia-Neves $M$, Palha JA: Lipocalin 2 is a choroid plexus acute-phase protein. I Cereb Blood Flow Metab 2008, 28(3):450-455.

13. Marques F, Falcao AM, Sousa JC, Coppola G, Geschwind D, Sousa N, Correia-Neves M, Palha JA: Altered iron metabolism is part of the choroid plexus response to peripheral inflammation. Endocrinology 2009, I 50(6):2822-2828.

14. Brown DA, Sawchenko PE: Time course and distribution of inflammatory and neurodegenerative events suggest structural bases for the pathogenesis of experimental autoimmune encephalomyelitis. J Comp Neurol 2007, 502(2):236-260.

15. Reboldi A, Coisne C, Baumjohann D, Benvenuto F, Bottinelli D, Lira S, Uccelli A, Lanzavecchia A, Engelhardt B, Sallusto F: C-C chemokine receptor 6-regulated entry of $T(H)-I 7$ cells into the CNS through the choroid plexus is required for the initiation of EAE. Nat Immunol 2009, I0(5):5 I4-523.

16. Golabek A, Marques MA, Lalowski M, Wisniewski T: Amyloid beta binding proteins in vitro and in normal human cerebrospinal fluid. Neurosci Lett 1995, I 9 I ( I-2):79-82.

17. Carro E, Spuch C, Trejo JL, Antequera D, Torres-Aleman I: Choroid plexus megalin is involved in neuroprotection by serum insulin-like growth factor I. J Neurosci 2005, 25(47): I0884-I0893.

18. Berman JS, Cruikshank WW, Center DM, Theodore AC, Beer DJ: Chemoattractant lymphokines specific for the helperl inducer T-lymphocyte subset. Cell Immunol I 985, 95(I): I 05-I I 2.

19. Cruikshank W, Center DM: Modulation of lymphocyte migration by human lymphokines. II. Purification of a lymphotactic factor (LCF). J Immunol 1982, I 28(6):2569-2574.

20. Laberge S, Pinsonneault S, Varga EM, Till SJ, Nouri-Aria K, Jacobson M, Cruikshank WW, Center DM, Hamid Q, Durham SR: Increased expression of IL- 16 immunoreactivity in bronchial mucosa after segmental allergen challenge in patients with asthma. J Allergy Clin Immunol 2000, I 06(2):293-30I.

21. De Bie J, Jonker EH, Henricks PA, Hoevenaars J, Little FF, Cruikshank WW, Nijkamp FP, Van Oosterhout AJ: Exogenous interleukin- 16 inhibits antigen-induced airway hyper-reactivity, eosinophilia and Th2-type cytokine production in mice. Clin Exp Allergy 2002, 32(I I): I 65।-1658.

22. Kaser A, Dunzendorfer S, Offner FA, Ryan T, Schwabegger A, Cruikshank WW, Wiedermann CJ, Tilg $\mathrm{H}$ : A role for IL- 16 in the crosstalk between dendritic cells and T cells. J Immunol 1999, I 63(6):3232-3238.

23. Lynch EA, Heijens CA, Horst NF, Center DM, Cruikshank WW: Cutting edge: IL-I6/CD4 preferentially induces ThI cell migration: requirement of CCR5. I Immunol 2003, I 7 I ( I 0):4965-4968.

24. McFadden C, Morgan R, Rahangdale S, Green D, Yamasaki H, Center $D$, Cruikshank W: Preferential migration of $T$ regulatory cells induced by IL-I 6. J Immunol 2007, I 79( I 0):6439-6445.

25. Li HS, Chen JH, Wu W, Fagaly T, Zhou L, Yuan W, Dupuis S, Jiang $\mathrm{ZH}$, Nash W, Gick C, et al.: Vertebrate slit, a secreted ligand for the transmembrane protein roundabout, is a repellent for olfactory bulb axons. Cell 1999, 96(6):807-818.

26. Wu W, Wong K, Chen J, Jiang Z, Dupuis S, Wu JY, Rao Y: Directional guidance of neuronal migration in the olfactory system by the protein Slit. Nature 1999, 400(6742):331-336. 
27. Yoshida J, Kubo T, Yamashita T: Inhibition of branching and spine maturation by repulsive guidance molecule in cultured cortical neurons. Biochem Biophys Res Commun 2008, 372(4):725-729.

28. Schwab JM, Monnier PP, Schluesener HJ, Conrad S, Beschorner R, Chen L, Meyermann R, Mueller BK: Central nervous system injury-induced repulsive guidance molecule expression in the adult human brain. Arch Neurol 2005, 62(10): I56I-I568.

29. Siu FK, Sham MH, Chow BK: Secretin, a known gastrointestinal peptide, is widely expressed during mouse embryonic development. Gene Expr Patterns 2005, 5(3):445-45I.

30. Yamagata T, Urano H, Weeber EJ, Nelson DL, Nishijima I: Impaired hippocampal synaptic function in secretin deficient mice. Neuroscience 2008, 154(4): 1417-I422.

31. Hwang DW, Givens B, Nishijima I: Ethanol-induced developmental neurodegeneration in secretin receptor-deficient mice. Neuroreport 2009, 20(7):698-70I.

32. Emerich DF, Skinner SJ, Borlongan CV, Vasconcellos AV, Thanos CG: The choroid plexus in the rise, fall and repair of the brain. Bioessays 2005, 27(3):262-274.

33. Giovannoni G: Multiple sclerosis cerebrospinal fluid biomarkers. Dis Markers 2006, 22(4): 187-196.

34. Geroldi D, Falcone C, Emanuele E: Soluble receptor for advanced glycation end products: from disease marker to potential therapeutic target. Curr Med Chem 2006, I3(17): 1971-1978.

35. Husemann J, Loike JD, Anankov R, Febbraio M, Silverstein SC: Scavenger receptors in neurobiology and neuropathology: their role on microglia and other cells of the nervous system. Glia 2002, 40(2): 195-205.

36. Murphy JE, Tedbury PR, Homer-Vanniasinkam S, Walker JH, Ponnambalam S: Biochemistry and cell biology of mammalian scavenger receptors. Atherosclerosis 2005, I82(I): I-I5.

37. Zlokovic BV: Clearing amyloid through the blood-brain barrier. J Neurochem 2004, 89(4):807-8II.

38. Bullard DC, Hu X, Schoeb TR, Collins RG, Beaudet AL, Barnum SR: Intercellular adhesion molecule-I expression is required on multiple cell types for the development of experimental autoimmune encephalomyelitis. J Immunol 2007, I 78(2):85I-857.

39. Gentleman RC, Carey V], Bates DM, Bolstad B, Dettling M, Dudoit S, Ellis B, Gautier L, Ge Y, Gentry J, et al.: Bioconductor: open software development for computational biology and bioinformatics. Genome Biol 2004, 5(I 0):R80.

40. Rozen S, Skaletsky H: Primer3 on the WWW for general users and for biologist programmers. Methods Mol Biol 2000, 132:365-386.

Publish with Biomed Central and every scientist can read your work free of charge

"BioMed Central will be the most significant development for disseminating the results of biomedical research in our lifetime. "

Sir Paul Nurse, Cancer Research UK

Your research papers will be:

- available free of charge to the entire biomedical community

- peer reviewed and published immediately upon acceptance

- cited in PubMed and archived on PubMed Central

- yours - you keep the copyright

Submit your manuscript here:

http://www.biomedcentral.com/info/publishing_adv.asp
BiolMedcentral 